\title{
Influence of rotary diamond and ultrasonic tips on bond strength of composite cingulum rest seats over dentin
}

\author{
Influência de pontas diamantada e ultrassônica na resistência \\ de união de descanso para apoio de cíngulo em resina \\ composta sobre dentina
}

\begin{abstract}
Purpose: To evaluate the influence of using either ultrasonic CVD (Chemical Vapor Deposition) or conventional rotary diamond tips on the adhesive strength of cingulum rest seats made of composite resin over bovine dentin.

Methods: Twenty specimens were produced for each experimental group. For specimens in Group 1, the dentin was exposed with a rotary diamond tip; in Group 2 this procedure was performed using an ultrasonic CVD diamond tip. In both groups a two-step self-etching adhesive system was used, and the shape and size of the rest seats made of composite resin were standardized. The specimens were subjected to a shear assay using a universal testing machine at a crosshead speed of $0.5 \mathrm{~mm} / \mathrm{min}$. Data were analyzed by Student's t-test at the significance level of 0.05 .

Results: There was a statistically significant difference $(P=0.028)$ between the means of the experimental groups: 24 kgf for Group 1 and 31 kgf for Group 2.

Conclusion: Dental preparation with dentin exposure in the cingulum region by using ultrasonic CVD diamond tip showed the highest bond strength of self-etching adhesive system and composite rest seats for support of removable partial dentures.
\end{abstract}

Key words: Removable partial prosthesis; composite rest seat

\section{Resumo}

Objetivo: Avaliar a influência do uso de pontas ultra-sônica em diamante CVD e de pontas rotatórias convencionais na força adesiva do descanso para apoio de cíngulo em resina composta, confeccionadas sobre dentina de dente bovino.

Metodologia: Foram confeccionados 20 espécimes para cada grupo experimental. A exposição dentinária foi realizada com a ponta diamantada rotatória nos espécimes do Grupo 1 e com ponta diamantada CVD no Grupo 2. Em ambos os grupos foi utilizado um sistema adesivo autocondicionante de dois passos. A forma e o tamanho do descanso em resina composta foram padronizados com uma matriz de acetato. Os espécimes foram submetidos ao ensaio de cizalhamento em máquina de teste universal com velocidade constante de $0,5 \mathrm{~mm} / \mathrm{min}$. Os dados foram analisados por teste t de Student ao nível de significância de 0,05.

Resultados: $O$ teste t-Student demonstrou diferença estatisticamente significante entre os grupos $(P=0,028)$, com médias de 24 kgf para o grupo 1 e 31 kgf para o grupo 2 .

Conclusão: $\bigcirc$ preparo dental com exposição de dentina em região de cíngulo com ponta ultra-sônica CVD promoveu maior resistência de união do sistema adesivo autocondicionante com o descanso para apoio de cíngulo em resina composta para uso em prótese parcial removível.

Palavras-chave: Prótese parcial removível; descanso em resina

\author{
Gustavo Salgado de Souza a \\ Welton Bohry de Souza b \\ Jose Luiz Rezende Bispo dos Santos ${ }^{a}$ \\ Eliza Burlamaqui Klautau a \\ João Evandro da Silva Miranda a
} - Graduate Program in Dentistry (Masters), Federal
University of Pará, Belém, PA, Brazil
b Undergraduate Dental Course, Federal University
of Pará, Belém, PA, Brazil

\author{
Correspondence: \\ Gustavo Salgado de Souza \\ Travessa Rui Barbosa 1208; Bairro Nazaré \\ Belém, PA - Brasil \\ 66035-220 \\ E-mail:gustavo_salgado@globo.com
}

Received: March 2, 2010

Accepted: February 22, 2011

Conflict of Interest Statement: The authors state that there are no financial and personal conflicts of interest that could have inappropriately influenced their work.

Copyright: (C) 2011 Souza et al.; licensee EDIPUCRS. This is an Open Access article distributed under the terms of the Creative Commons AttributionNoncommercial-No Derivative Works 3.0 Unported License. 


\section{Introduction}

The rest seats for a removable partial prosthesis are produced by using tips that wear down the enamel. However, in the cingulum region of the mandibular anterior teeth, this procedure may be risky due to possible dentin exposure leading to pain, sensitivity, decalcification and fracture (1-3). Nevertheless, these rest seats in the cingulum are important for the successful functioning of removable partial prostheses, and they present biomechanical and aesthetic advantages over incisal rest seats. Locating the rest seat in the cingulum of the anterior teeth, closer to the axis of rotation of the supporting teeth, decreases the strength lever in relation to the resistance lever and transmit the axial forces more efficiently. In addition, this method does not compromise the aesthetics of the tooth, as the cingulum rest seats usually cannot be seen in the buccal region. On the other hand, the incisal rest seats often compromise the dental aesthetics as they invade the buccal region and are positioned along the axis of dental rotation (4-6).

An alternative clinical procedure to combine the aesthetics and biomechanics advantages of the rest seats located in the anterior teeth is to add photopolymerized composite resin to the cingulum. This method usually preserves dental tissue, is aesthetically pleasing, is affordable, is easy to handle, and decreases clinical time. Its main disadvantage is the possibility of fracturing the composite resin, but this is easy to repair clinically (7).

In case of a possible dentin exposure with direct preparation, the technique of producing a composite resin bridge can be used to occlude the dental tubules. The objective of this study was to evaluate the influence of using ultrasonic CVD diamond tips and conventional rotary diamond tips on the bond strength of the composite resin rest seats prepared over the cingulum dentin.

\section{Methodology}

Twenty specimens of bovine mandibular incisors were prepared for each of the two experimental groups. In group 1 , dentin exposure at the cingulum region was performed by using a conventional 2214 rotating tip (KG Sorensen, São Paulo, SP, Brazil); in group 2, the same procedure was accomplished by using an ultrasonic CVD diamond silver C1 series tip (CVDentus ${ }^{\circledR}$ CVD Vale, São Jose dos Campos, SP, Brazil), attached to CVDent1000 Ultrasound equipment (CVDentus ${ }^{\circledR}$ CVD Vale, São Jose dos Campos, SP, Brazil) set at level 3. Two CVD tips were used for 10 preparations each, and 4 diamond tips were used for 5 preparations each. We followed the methodology of Moreira Junior (8).

The tips were positioned parallel to the cingulum of the tooth, forming a quadrilateral plane of approximately $6.0 \times 6.0 \mathrm{~mm}$ of dentin without retention of enamel on the edges. To standardize the inclination of the teeth, a matrix in the shape of an oblong triangle was prepared using self-polymerized resin (Vipi Produtos Odontológicos, Pirassununga, SP, Brazil; Lot: 76604 ) at $19^{\circ}, 71^{\circ}$, and $90^{\circ}$ angles. This triangle was created as an alignment tool to standardize the inclination at $19^{\circ}$ for the bovine teeth during setting in PVC tubes (Tigre S/A, Joinville, SC, Brazil) in a plaster casting stone (Vigodent SA Indústria e Comércio, Rio de Janeiro, RJ, Brazil), with the triangle connected to the mandrel of alignment tool (Bioart Equipamentos Odontológicos, São Carlos, SP, Brazil) through its metal rod. The tooth was fixed with cyanoacrylate adhesive (Superbond, Henkel Ltda, São Paulo, SP, Brazil) at an angle of $71^{\circ}$ to form a $19^{\circ}$ angle in relation to the long axis (Fig. 1).

The crown of a bovine tooth was used to prepare a matrix to standardize the volume and shape of the rest seat in the cingulum region. A photopolymerized composite resin, Z350 color A3 (3M ESPE Dental Products, St. Paul, MN, USA; Lot: 8PU), was packed with the incremental technique. The simulated composite resin restoration had the shape of an inverted "V" with the dimensions of $4.0 \mathrm{~mm}$ in the mesialdistal direction, 4.0 in the incisor-cervical direction, and $2.0 \mathrm{~mm}$ in the buccal-lingual direction. Transparent acetate matrices were produced using a Denplast crown laminator (Equipamentos Odontológicos Den-Prov, São José do Rio Preto, SP, Brazil) to duplicate the matrix shape and volume.

For the specimens in Group 1, dental preparation was performed using a 2214 diamond tip, with incisor-cervical movements parallel to the tooth (Fig. 2), to obtain a flat plane of $6.0 \times 6.0 \mathrm{~mm}$ exposed dentin, with no retentive edges. Specimens in Group 2 were prepared using the ultrasonic CVD diamond plated C1 Series tip regulated by the ultrasound equipment at level 3 with incisor-cervical movements parallel to the tooth (Fig. 3).

Clearfill SE Bond self-etching adhesive (Kuraray America Inc., New York, NY, USA; Lot: Primer 00788A, Bond 01144A) was applied to the bonding surface of all specimens. The initial primer layer was applied for $20 \mathrm{~s}$ and then gently air-dried for $2 \mathrm{~s}$. The bonding agent was applied and photopolymerized (Ultraled, Dabi Atlante, Ribeirão Preto, SP, Brazil) for $10 \mathrm{~s}$. The Z350 composite resin was inserted in the central region of the dentin cingulum preparation, with the aid of the matrix, and polymerized for $60 \mathrm{~s}$.

The specimens were stored in distilled water at $37^{\circ} \mathrm{C}$ for 3 days before being subjected to a mechanical shear assay using a universal testing machine (Kratos, São Paulo, SP, Brazil) at a crosshead speed of $0.5 \mathrm{~mm} / \mathrm{min}$. The tip of the force applicator was positioned at the resin/dentin interface in the incisor-cervical direction (Fig. 4). The values of maximum tensile force for the compression were obtained automatically by using the universal testing machine software, and the numbers were transformed from Newtons into kilogram-force (1 kgf=9.8066 N). The parametric Student's t-test was used for data analysis at the significance level established at $\alpha=0.05$. 




Fig. 1. Setting of a bovine tooth with the help of matrix lined with standardized angles.



Fig. 2. Preparation of the cingulum region with a rotary diamond tip.



Fig. 3. Preparation of the cingulum region with a CVD tip.

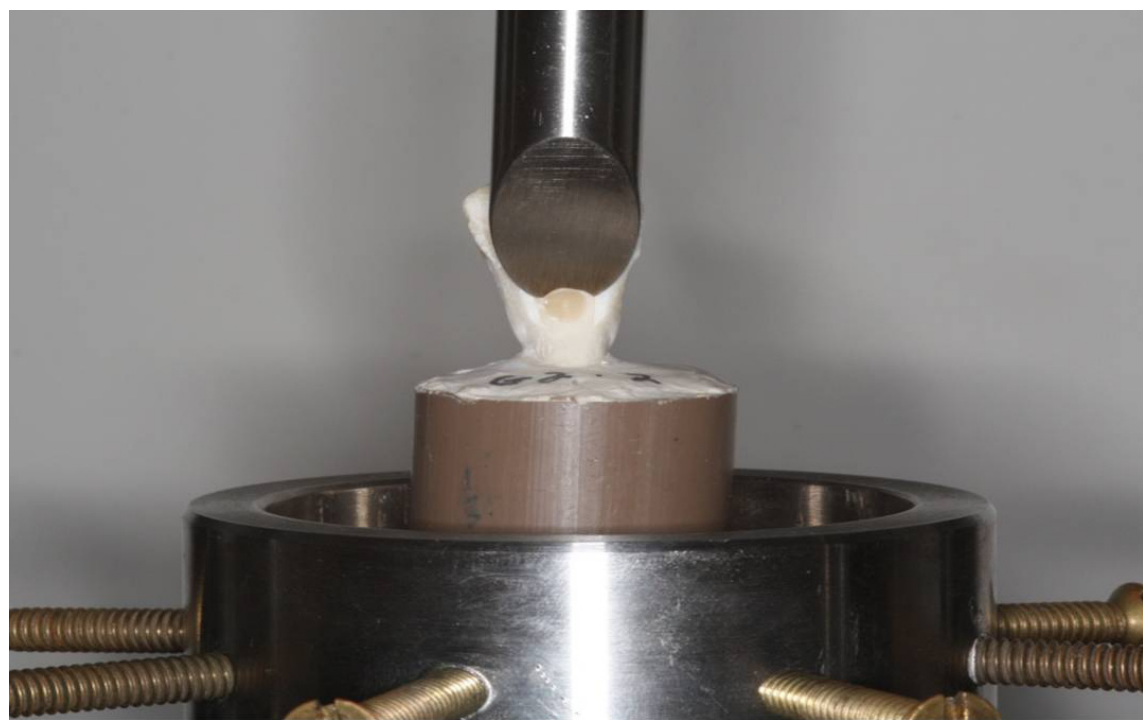

Fig. 4. Mechanical shear assay using a universal testing machine. 


\section{Results}

The descriptive statistics of both groups are depicted in Table 1. The Student's t-test showed that the mean bond strength value of Group 2 (CVD tip) was significantly higher than the mean value of Group 1 (rotary diamond tip) $(P=0.028)$.

Table 1. Descriptive statistics of Groups 1 and 2 ( $n=20$ per group) in relation to the maximum bond strength (in kilogram-force).

\begin{tabular}{lcc}
\hline \multicolumn{1}{c}{ Descriptive Statistics (kgf) } & Group 1 & Group 2 \\
\hline Minimum value & 13.35 & 12.00 \\
Maximum value & 38.55 & 50.25 \\
Mean & 24.08 & 31.13 \\
Standard deviation & 7.40 & 11.68 \\
Coefficient of variation & $30.7 \%$ & $37.5 \%$ \\
\hline
\end{tabular}

\section{Discussion}

In general, the rest seats for removable partial dentures are prepared over enamel, have a negative shape and transmit the chewing forces along the axis of the support teeth $(9,10)$. The rests act as direct and indirect retainers of removable partial dentures and are fundamental to the prosthesis biomechanics $(4,7,9,10)$. The preparation of rest seats in the cingulum is required for partial class I and II Kennedy dentures as they act as indirect retainers to avoid lever movements caused by the lack of posterior teeth, thus stabilizing the prosthetic device (11).

There are two possibilities for the preparation of rest seats in the anterior teeth: in the cingulum and incisal areas. The rest in the cingulum has the biomechanical advantage of locating the rest close to the fulcrum of rotation of the supporting teeth, thus avoiding unnecessary torque that occurs with the incisal rests. Another advantage of the cingulum rest is the improved aesthetics of the rest seat, which is positioned close to the tongue or palate, in contrast with the incisal rest that may be seen at the buccal face (4-6).

The major disadvantage in the preparation of a direct rest seat in the cingulum using diamond drill is the possibility of dentin exposure, which may cause pain, sensitivity, decalcification and fractures. Dentin exposure may occur because the lingual region of anterior teeth usually has no sufficiently thick enamel (1-3) as required for this type of preparation. In general, a large $2.0-\mathrm{mm}$ lingual-buccal thickness is necessary to prepare rest seats in the cingulum region (5).

To solve this problem, a method to thicken the structure of the cingulum using a photopolymerized resin composite has been proposed (12-15). In addition, the supports over the rest seats that are prepared with composite resin are better adapted than rest seats over enamel (15). The rest seat made of composite resin is easy to handle, decreases the denture preparation time, is aesthetics and conserves dental tissue. The disadvantage is the possibility of fracture (7). Due to the advantages of using composite resin, studies have been performed with the goal of increasing the clinical durability of this technique as well as the resin's resistance to fracture. Some previous studies investigated the performance of the resin rest seat over a dentin substrate, which leads to adhesion strength values lower than those on enamel $(16,17)$.

In the present study, dentin exposure was simulated using a conventional rotary drill and an ultrasonic CVD diamond tip. There is evidence that during dental wear with conventional rotary points a smear layer is formed, which promotes the obstruction of the dentin tubules and may decrease the adhesive strength of the restoration $(8,18-20)$.

Maxfield et al. (21) calculated the load on a single rest to be $2.0 \mathrm{kgf}$, yet this study was limited to a small number of cases of patients rehabilitated with partial removable dentures and complete dentures. In another study, Costa et al. (12) multiplied $2.0 \mathrm{kgf}$ by five times, suggesting a margin of safety for fracture resistance of the rest seat made of composite resin. The values of maximum fracture force over dentin in the present study exceeded the value established by Costa et al. (12) by approximately three times. These results also agreed with the subsequent study by Costa et al. (13), who used dentin in the shear assays. However, our results are lower than those obtained by Prado et al. (14), who used a conventional three-step adhesive system on enamel. The conventional three-step adhesive system seems to be superior to the simplified conventional adhesive systems and is far superior to the self-etching ones (22).

The fact that the pre-established minimum value of $10 \mathrm{kgf}$ (12) was surpassed suggests that the self-etching adhesive provides adequate bond strength to dentin and the cingulum rest seat in composite resin, even when using a rotary diamond point. There was improved bond strength of the self-etching system with the use of CVD tips, which was probably because of the decrease in dentin smear layer (23) due to the formation of micro-bubbles from the ultrasound, which favors the release and clearing of the smear layer $(8,18-20)$. The smear layer should be removed to improve the bond strength. Depending on how the smear layer is treated and on its thickness, it may serve as a barrier to the diffusion of the monomers of the self-etching primers. The greater the thickness of the smear layer is, the greater the difficulty that the self-etching systems will have in spreading into the underlying dentin to yield a high bond strength $(24,25)$.

The direct preparation of a rest seat in the cingulum is risky. This risk may be reduced with CVD tips, which cut slowly, do not produce pain or sensitivity, have greater precision and less noise, and produce less smear layer than conventional rotary points (18). If during the direct preparation an accident occurs and the enamel layer is perforated, the enamel may be removed safely. The fabrication of a cingulum rest seat in composite resin, either directly or using the transparent matrix technique, may favor the bond strength of the restorative material when the CVD tip is used over fractured enamel. The CVD tip reduces the formation of smear layer as often occurs while using conventional rotary tips for removal of fractured enamel (18-20). 
The technique of fabricating rest seats in composite resin is clinically relevant because of the high demand for removable partial dentures for oral rehabilitation due to socioeconomic factors, the need for rapid denture construction, and the flexibility to solve the various forms of partial edentulism. This technique offers effective indirect retention and is the safest way to maintain the structural integrity of the anterior teeth while avoiding unnecessary direct preparations. Therefore, the findings of the present study support the use of cingulum rest seats in composite resin over dentin, which may be useful in cases of enamel perforation to improve bond strength of the composite resin restoration.

\section{Conclusions}

Dental preparation with dentin exposure in the cingulum region by using ultrasonic CVD diamond tip showed the highest bond strength of self-etching adhesive system and composite rest seats for support of removable partial dentures.

References 1. Jones RM, Goodacre CJ, Brown DT, Munoz CA, Rake PC. Dentin expossure and decay incidence whem removable partial denture rest seats are prepared in tooth structure. Int J Prosthodont 1992;5:227-36.

2. Likeman PR, Juszczyk AS. An examination of cingulum rest seats in incisor and canine teeth. Eur J Prosthodont Restor Dent 1993;1:165-71.

3. Mengar MA. Investigação sobre a espessura do esmalte remanescente após preparações de descansos de cíngulo realizados em caninos superiores, por intermédio do microscópio óptico de luz [Dissertation]. São Paulo (SP): Faculdade de Odontologia da Universidade de São Paulo; 1996.

4. Fiori SR. Atlas de prótese parcial removível. 4a ed. São Paulo (SP): Panamed; 1993.

5. McGivney GP, Castleberry DJ. Prótese parcial removível de McCraken. 8 ed. São Paulo: Artes Médicas; 1994.

6. Seto BG, Caputo AA. Photoelastic analysis of stresses in resin-bonded cingulum rest seats. J Prosthet Dent 1986;56:460-5.

7. Vedovato $E$, Bottino MA. Uso de resina fotopolimerizável em apoios para prótese parcial removível. Rev Inst Cienc Saúde 1999; 17:57-60.

8. Moreira Junior MT. Análise por microscopia eletrônica de varredura da "smear layer" produzida em preparos com pontas diamantadas e pontas CVD [Dissertation]. Belém (PA): Faculdade de Odontologia da Universidade Federal do Pará; 2008.

9. Glickman I. The periodontal structures and removable partial denture prosthesis. J Am Dent Assoc 1948;37:311-6.

10. Henderson D, Steffel VL. Prótesis parcial removible según Mccracken. Buenos Aires: Mundi; 1974.

11. Berg Jr T, Caputo AA. Anterior rest for maxilary removable partial dentures. J Prosthet Dent 1978;39:139-46.

12. Costa B, Galvan R, Navarro H, Muench A, Todescan R. Apoios de cíngulo em resina composta para prótese parcial removível: aspectos da sua viabilidade clínica. Rev Assoc Paul Cir Dent 1991;45:495-9.

13. Costa B, Galvan R, Mutarelli P, Navarro H, Oliveira MA. Descanso sobre cíngulo de resina composta aplicada em esmalte e dentina. Rev Assoc Paul Cir Dent 1998;52:29-33.

14. Prado CJ, Biffi JC, Fernandes AJ, Neves FD, Costa MM. Avaliação da resistência ao cisalhamento de nichos de resina composta. Rev Bras Prot Clin Lab 2001;3:83-6.

15. Nagayassu MP, Murakami JT, Nogueira Junior L, Pavanelli CA, Uemura ES. Avaliação clínica da adaptação de apoios em cíngulo para prótese parcial removível. Cienc Odontol Bras 2005;3:22-8.

16. Kugel G, Ferrari M. The science of bonding: from first to sixth generation. J Am Dent Assoc 2000;131:20-5.

17. Van Meerbeek B, De Munck J, Yoshida Y, Inoue S, Vargas M, Vijay P, Van Landuył K, Lambrechts P, Vanherle G. Buonocore memorial lecture. Adhesion to enamel and dentin: current status and future challenges. Oper Dent 2003;28: 215-35.

18. Vieira D, Vieira DF. Pontas de diamante CVD: Início do fim da alta rotação? J Am Dent Assoc 2002;5:307-13.

19. Macedo MRP. Características da superfície dentinária e do esfregaço formado por instrumentos abrasivos diamantados: rotatório convencional, CVD rotatório e CVD por ultra-som. Estudo in vitro [Dissertation]. São Paulo (SP): Faculdade de Odontologia da Universidade de São Paulo; 2005.

20. Martins MEL, Faria MR, Matson MR. Análise micromorfológica da dentina humana condicionada por primer autocondicionante variando-se a técnica de preparo: Ponta diamantada, broca carbide, ponta CVDentus. Pesq Bras Odontoped Clin Integr 2006;6:161-6. 
21. Maxfield J, Nicholis JI, Smith DE. The measurement of forces transmitted to abutment teeth of removable partial dentures. J Prosthet Dent 1979;41:134-42.

22. Göhring TN, Schonenberger KA, Lutz F. Potencial of restorative systems with simplified adhesives: quantitative analisys of wearand marginal adaptation in vitro. Am J Dent $2003 ; 16: 275-82$.

23. Carvalho RM, Carrilho MRO, Pereira LCG, Garcia FCP, Marquezini L, Silva SMD. Sistemas adesivos: fundamentos para a aplicação clínica. Biodonto $2004 ; 2: 1-89$.

24. Nakabayashi I, Saimi Y. Bonding to intact dentin. J Dent Res 1996;75:1706-15.

25. Nakabayashi N, Pashley N, David H. Hibridização dos tecidos dentários duros. São Paulo: Quintessence; 2000. 